\title{
The Postmodern Persistence of the Brazilian Development State: A Comparative Study of Policies During the Cardoso and Lula Administrations
}

Adam Talkington

Portland State University

Follow this and additional works at: https://pdxscholar.library.pdx.edu/mcnair Let us know how access to this document benefits you.

\section{Recommended Citation}

Talkington, Adam (2011) "The Postmodern Persistence of the Brazilian Development State: A Comparative Study of Policies During the Cardoso and Lula Administrations," PSU McNair Scholars Online Journal: Vol. 5: Iss. 1, Article 23.

https://doi.org/10.15760/mcnair.2011.256

This open access Article is distributed under the terms of the Creative Commons Attribution-NonCommercialShareAlike 4.0 International License (CC BY-NC-SA 4.0). All documents in PDXScholar should meet accessibility standards. If we can make this document more accessible to you, contact our team. 
Portland State University McNair Research Journal 2011

The Postmodern Persistence of the Brazilian Development State: A Comparative Study of Policies During the Cardoso and Lula Administrations

\author{
by \\ Adam Talkington
}

Faculty Mentor:

Leopoldo Rodriguez

Citation: Talkington, Adam. The postmodern persistence of the Brazilian development state: A comparative study of policies during the Cardoso and Lula administrations. Portland State University McNair Scholars Online Journal, Vol. 5, 2011: pages [257-307] 


\section{The Postmodern Persistence of the Brazilian Development State:}

\section{A Comparative Study of Policies During the Cardoso and Lula Administrations}

\section{Adam Talkington \\ Faculty Mentor: Leopoldo Rodríguez, PhD}

Abstract: This paper seeks to define and compare Brazilian national development strategies during the Cardoso and Lula administrations. Assuming a political economy perspective, we first provide a context for understanding contemporary Brazilian development by defining the developmental state characterizing Brazilian governance from 1930 to 1985, followed by an overview of the theoretical arguments underlying the reform process. Using an historical deductive methodology, we explore the national development strategies of the two administrations through a narrative of their divergent agendas and the economic and social policies they engendered. Finally, we consider the similarities and distinctions between development policies occurring in the periods under analysis, drawing attention to the evolving character and role of a reformed, but still intact, developmental state in Brazil.

\section{Introduction}

The beginning of the $21^{\text {st }}$ century marked an apparent change in Latin American politics. Brazil, like many of its neighbors, elected a leader that seemed to represent a decisive turn away from the "neoliberal” agenda that characterized policy-making in the 1990s. Upon taking office, however, this new, leftist president_Luiz Inacio Lula da Silva (Lula)—maintained the economic model of his predecessor, Fernando Henrique Cardoso (FHC). In spite of president Lula’s apparent failure to install a new economic model, his presidency has produced marked advances in the area of social welfare policy, restoring much of the progressive credit granted him by his history as union organizer and Worker Party(PT) leader. Much of this success, however, rests on the policies enacted during the FHC presidencies - a fact which suggests that, in Brazil, the famous "turn to the left" may not have occurred. Certainly, as Molyneux (2008) suggests, the paradoxical links between an administration focused on state reform (FHC), and one which 
ostensibly serves as a bastion for progressive policy-making, warrants a more nuanced and historically grounded inquiry.

Understanding the relationship between policies made during the FHC and Lula administrations hinges on a comprehension of Brazil's distinct brand of developmentalism. While much analysis has been made of the political and ideological factors involved in contemporary policy-making, this has often lacked an appropriate consideration of the historical and institutional factors providing the context. Simply put, economic and social policies cannot be considered only in the context of the most influential ideas of the time; they must also be considered in the context of their overall intent; their function in the overall plan. In the case of Brazil, contemporary policy-making must be viewed in light of the government's longstanding and explicit role in guiding national development. Thus, in order to understand the comparative experiences of the FHC and Lula periods, one must focus less on the differ from each other, and more on how they work in connection with each other as part of a new stage in national development. While both internal and international factors have brought on profound change to economic, political, and social realities, these have only sparked the continual evolution of a development strategy with a strong role for government.

\section{The Old Developmentalism}

The Brazilian developmental state began in 1930, with the revolution that put Gétulio Vargas in power. The 1930 revolution laid to rest the Old Republic, a period when a powerful landed aristocracy governed Brazil in oligarchic fashion, with governors of states like São Paulo and Minas Gerais wielding great national power ${ }^{1}$. Vargas assumed the presidency with an explicit agenda for modernizing Brazilian society. This modernizing vision sought to develop a

\footnotetext{
${ }^{1}$ For a detailed overview of Vargas’ rise to power and enigmatic political style see Bak (1983).
} 
national industrial base through alliances with the nascent Brazilian capitalist and commercial classes. The implementation of this vision initiated the beginning of a state-led development model, culminating in 1937 with the Estado Novo (New State), a dictatorial regime making use of every type of intervention, including political repression. Two dimensions of the modernizing government model established under the Vargas regime register as particularly relevant. First, the state became the primary agent of development. Its role in the economy went far beyond stimulating supply and demand; the new government provided a vision for the economy and pursued it aggressively. Second, this model of government sought to reorganize and control society through installing an authoritarian corporatist model of state-society relations. In other words, the state assumed a pivotal role in both economic and social development, a role that both coincided with, and provided rationale for a new centralized power structure.

Breaking from the decentralized, federalist structure of the Old Republic, the Vargas regime established a strong, interventionist central government. In contrast to the Café com Leite $^{2}$ order of the past, the Vargas regime operated with a clear bias toward industrial urban sectors, creating new modes of intervention, consolidated in a central government. This strong central government regulated and invested directly in productive sectors, in a mode of economic intervention that came to be known as import substitution industrialization (ISI). Utilizing subsidies, protective tariffs, and direct investment the government actively promoted an industrial revolution (Pereira, 2009). State agencies were erected in order to regulate vital sectors of the economy, such as water, power, steel, coffee, and sugar. The state even assumed a role as producer, financing a large state-owned steel company through the U.S. Eximbank. In order to operate the new interventionist state and reorganize society in a modern, controlled fashion,

${ }^{2}$ Café com Leite refers to the political dominance of the governors of São Paulo (representative of coffee producers) and Minas Gerais (representative of its dairy industry). 
Vargas reorganized the channels of governance and representation, contributing to the other major legacy of the Vargas era: a corporate institutional framework.

The push to modernize Brazil's society and economy leaned heavily upon a revolution in the mode of political representation. In harmony with the bias toward urban, industrial classes, the Vargas regime imposed a corporate model of representation. With industrialist and military support of a state-led modernization, the Vargas regime initiated a restructuring of unions as the primary channel for working class representation. This process of societal reorganization utilized repressive and propagandist means, disciplining politicians, union leaders, and anyone else that posed a threat to the vision of the Estado Novo. Two major institutional characteristics emerged from this process. First, the development state emerged in the context of a coalition between the federal government, the nascent national industrial bourgeoisie, and the working class; this alliance would later come to clash with the centralized, modernist state's tendency toward coercive means. Given this structure, interest groups could only influence government policy through state regulated channels, providing the power elite with further insulation from the working class. Second, society's new order and economic revolution came at the hands of an authoritarian, quasi-fascist government. The more government institutions were used to impose order in economic and social arenas, the easier it became for the apparatuses of power to be exercised in more untenable ways.

With the Vargas dictatorship overthrown in 1945 by military coup, the intervening and corporate characteristics of the government carried over into a period of fragile democratic rule. The shift in politics brought with it a new constitution in 1946, which reflected the desire of many to move away from the centralized power structure of the preceding personal dictatorship. Yet the process of nation building resumed, creating an obstacle for decentralization. After a 
conservative period of governing, characterized by repression of labor movements, unions, and leftist politics, Vargas was re-elected with a more populist agenda. During this period, the government assumed a more pro-labor and nationalist position, increasing the minimum wage and shunning foreign capital. Major institutions were erected: the National Economic Development Bank (BNDE), Electrobrás (the state electricity producer and provider), and Petrobrás (the state petroleum company), bringing with them an expansion of state investment in infrastructure and productive sectors.

After a dramatic end to the Vargas presidency, Juscelino Kubitschek took office, carrying on the tradition of a now populist, centralized development state. Kubitschek implemented the most coherent industrialization program to date, which greatly expanded the federal government's role in investment. Moreover, the Kubitschek government added a new, controversial dynamic to the nation's development process: the promotion of foreign capital. Though successful in terms of industrial development and growth, the Kubitschek government spent beyond its means, resulting in inflationary pressure and the beginnings of an institutional crisis. Growing disapproval from military factions soon ushered to an end the period of a democratically deliberated economic development policy. The tension between the developmental state's tendency to control society finally and its role as driver of the economy became too great.

The coup of 1964 resulted in a twenty-one year span of military rule. An alliance between the military elite and technocrats characterized the governing style of the dictatorship. Political dissenters experienced a violent purge. Economically, orthodox measures were taken to curb inflation and reduce the spending deficit. Real wages were depressed, protectionist policies were slightly relaxed, and subsidized credit was reduced. Prices of publicly produced goods and 
services were raised, in order to reduce effective subsidies, and, without domestic credit, Brazilian businesses were purchased by foreign, especially American, firms. This initiated the trifecta of national, international, and state-owned enterprises that would dominate the Brazilian economy until the 1990s. Though monetarist approaches to economic stability were implemented, the basic nature of state intervention and ownership persisted. Eventually, the lack of political legitimacy for the military dictatorship gained momentum in the milieu of economic turmoil set on by an external debt crisis. In this context, governance in Brazil became open to institutional reform, with various theoretical paradigms calling for reforms based on principles.

The turmoil of the 80s brought Brazil under the pressure of an external debt crisis and an internal crisis of government legitimacy. Having been dominated by a military dictatorship for two decades, the call for democracy emerged even stronger in the face of the authoritarian regime's inability to manage the crisis. On a fundamental level, the break from authoritarianism to democratic rule altered a cornerstone of the model of governance set up during the Vargas regime: statism. While the establishment of an effective democracy is an arduous and multifarious process, the return of civil rule to Brazil also brought a return to decentralization and a period of institutional instability ripe for state reform. While this brought change to an increasingly illegitimate political framework, it also exposed the separate, but related, role of the State as an economic and social agent.

\section{Underlying Theories of Development and Governance}

Development economics provided theoretical support for the modernizing, interventionist state. In basic terms, this paradigm of economic analysis focused on the need for government intervention to correct undesirable market outcomes (Fishlow, 1990). A major premise of development economics insisted that less-developed countries operate under distinct conditions 
than those in advanced countries. Countering the Ricardian theory of comparative advantage, Raul Prebisch argued that the relative backwardness and lack of economic development characterizing countries of the "periphery", should be attributed to the disequilibria inherent in the international market system, a structure confined to the power relations produced by the course of history. Prebisch identified a relationship of dependency in trade between periphery and core countries, with countries of the periphery, those producing primary commodities, at constantly declining terms of trade with core countries—or, those countries exporting industrial goods $^{3}$. This insight spawned new approaches to economic analysis ${ }^{4}$ and, more importantly, implied that government intervention was needed to correct the asymmetrical relationships resultant from historical processes, in internal markets as in external.

The structuralist paradigm postulates that structural rigidities in society prevent the market mechanism from functioning in the manner theorized by classical economists. Inconsistent growth, undesirable income distribution, disequilibria and an insufficient savings rate are all attributed to market failure. Consequently, government policy should aim to correct market failure, provide public goods, and ensure the proper rate of savings. Given the relative underdevelopment of peripheral countries ${ }^{5}$, government-led industrialization seemed an appropriate solution to overcoming historically derived obstacles. This approach proposed import substitution through state-led industrialization(ISI). The ISI approach advocated trade protectionism to protect infant industries, direct government involvement in developing

\footnotetext{
${ }^{3}$ This seminal contribution is generally referred to as the Prebisch-Singer Hypothesis, due to the coincidence of the two authors arriving independently at very similar conclusions, at more or less the same time. See Prebisch (1950) and Singer (1949).

${ }^{4}$ Both the dependency theorists and structuralist schools can be traced back to this important assertion within the field of development economics.

${ }^{5}$ The historical reasons for Brazil's underdevelopment can be found in the classic work by Celso Furtado, Formação Econômico do Brasil (1959).
} 
industrial sectors, social welfare though societal modernization, and price controls through regulation and government planning.

In the 1930s, classical economic analysis lost sway in Latin America, as it did in the advanced countries. With the Keynesian revolution and development economics on the upswing, heterodox economics dominated policy making, bringing forth the Welfare State in the industrialized countries and the Development State in many of the non-industrialized countries. With the crisis of the 1970s came a renewal of the classical economic paradigm: an ideological shift known broadly as neoliberalism. In the developing world, the lack of price stability and the pressing constraints of a growing debt crisis led analysts to begin critiquing theories that supported the role of the state in development. As a counterpoint to the heterodox assertion that market failure necessitates government intervention, neoliberal theorists responded that government too can produce failures, with possibly higher costs than those of the untouched market.

In essence, neoliberal economists object to the policy response of developmental economics. Deepak Lal (1983) provides four areas of debate between orthodoxy and, what he terms, the Dirigiste Dogma. He asserts that, in reviewing the history of interventionist policies, (i) supplanting the market mechanism often creates more distortions and disequilibria greater than those that would otherwise occur, (ii) the focus on macroeconomic policy design overlooks microeconomic exchanges, to the neglect of social welfare, (iii) free trade is the "hand-maiden of growth”, making protectionist trade policies unnecessary and often debilitating growth because of their escalating costs, (iv) government intervention for the purpose of equitable income distribution largely rests upon controversial ethical argument. Fundamentally, the argument against developmental economics claims that in every case—-trade, income distribution, 
industrial development, etc.- $-\mathrm{a}$ comparison of the resource and distortion costs of intervention to non-intervention results in the assertion that "imperfect markets are superior to imperfect planning" (Lal, 1983, p 106). ${ }^{6}$

The failure of the ISI development model, and the gaining influence of neoliberal policymaking left structuralism in a period of transition. Analysts identified areas of failure: 1) exchange-rate overvaluation discriminated against exports, contributing to the growing imbalance of the external account, 2) government expenditures grew faster than revenues, and 3) the focus on industrialization led to distorted development, with sectoral imbalances between agriculture and industry and an insufficient rate of labor absorption in industry (Leiva, 2008). Furthermore, the paradigmatic shift toward the neoclassical school of economics on the international level presented Latin America's development economists, primarily represented in Economic Commission on Latin America and the Caribbean (ECLAC), to address theoretical deficiencies in addressing short-term issues. As this view on policy-making came under evaluation, institutional reforms seemed a necessary step in the journey to re-encounter a path toward development.

The neostructuralist model of development takes into account the changing context for policy-making, but maintains that the government should pursue an active strategy of development. The ECLAC offers a summary of the neostructuralist approach to addressing the problems presented to the development process in Latin America ${ }^{7}$. Recognizing the lopsided development of industry, resultant from the heavy bias toward internal markets, the authors envisaged a modernization of the productive structure. In this view, the already existent

\footnotetext{
${ }^{6}$ For an additional argument advocating for the retraction of state intervention based on total cost comparison see Krueger (1991).

${ }^{7}$ See Sunkel, O. and Zuleta, G. (1990)
} 
industrial base, a manifest success of ISI, should compete in the export market and develop a dynamic comparative advantage, supported by government subsidies rather than protective trade barriers. Governments should also encourage an atmosphere conducive to technological learning and innovation. A major deficiency of past development strategies lay in the dependence on foreign technology; hence, a major element of the new development strategy should be to create and strengthen a system of innovation and technology sharing within countries. In addition, the ECLAC admonishes governments to create a macroeconomic environment stable enough for long-term capital accumulation, which should be invested in innovation and productive capability. Finally, in assessing the crisis facing Latin American governments, neostructuralist theorists recommend a renovation of the state. The state should use economic incentives and relative prices to engender a strategic vision for development, backed by a coalition of key social and political groups.

\section{FHC-A Reformist's Agenda}

Riding the wave of support from the success of the real plan, Fernando Henrique Cardoso began his first term with an ambitious reform agenda, primarily targeting financial stability. Though Cardoso's party, the PSDB, had opposed the drastic reforms of the Collor government, the growing influence of financial technicians within the party, the state's chronic fiscal crises—now exposed without the masking effect of inflation—and the dynamics of the party's political coalition with the PFL, a center-right party, led to the embrace of structural reforms (Power, 2001). Many of the reforms aimed at remedying some of the more questionable components of the 1988 constitution; but, on a more fundamental level, the reforms constituted an attempt to redefine the role of the state, especially in its functions as an agent of development. 
Shortly after assuming the presidency, the executive office released a document describing the crises facing the country as one of the state, resultant from past government policies and institutions. The structural issues facing Brazil, it was argued, required a new development strategy with a new—less dominant—role for government. This document, the Plano Diretor da Reforma do Aparelho do Estado (1995), called for administrative reforms, reductions in state protections, the break up of state monopolies, restructuring the social security system, and a more balanced budget. At the center of all of these reform agendas lay a focus on fiscal and monetary policies—corruption and mismanagement in these areas having contributed to the unsustainability of the old development model. With the containment of inflation having provided the administration with a majority of its political capital, it may be noted that nearly all the reforms pursued during the period seemed to hinge on the stability plan that helped bring FHC to power: the real plan.

The impetus for these reforms stemmed from arguments for a more efficient and effective state, yet reforms of this nature also found support in the principles underlying the Washington Consensus - a call for the virtual removal of the state from market activity in order to let flourish the market's superior efficiency. As a result, the fundamentally reformist agenda of the Cardoso administration is difficult to characterize, with an internationally influential ideology recommending a reduction of state intervention in a market society (Williamson, 1990) and a nationalist-originated call for a redefinition of the state's role in guiding development (Bresser Pereira, 1996), which also called for a redefinition of the government-state relationship. At the time, these perspectives clearly coalesced to influence politicians to push for the same reforms, but sorting out the degree to which each perspective defined the actual reforms carried out may 
be necessary to understand the emergent development model and the government's long term role within it.

\section{Macroeconomic Policy- FHC}

Having been elected with a mandate to establish economic stability, FHC pursued a macroeconomic model with this objective as a clear priority. The real plan served as the fundamental component of the government's promise of stability. This created a strong incentive to protect the success of the plan over and against other policy objectives. While the administration's agenda clearly expanded beyond the scope of macroeconomic stability, the characteristics and dynamics of the real plan demanded major concessions in other policy sectors. The primacy of inflationary management through a quasi-fixed currency regime reduced the flexibility of other macroeconomic policies—especially fiscal policy_and created the conditions for a self-perpetuating system of indebtedness and systemic un-competitiveness, catering to short-term investment flows. During the second FHC administration, the shortcomings of the plan were exposed by international financial fluctuations, leading the government to allow a floating currency regime and dedicate itself further to programmatic fiscal balance.

Designed by economists within the PSDB and articulated by Cardoso, the real plan was the last of a series of programmatic attempts to bring inflation under control (Power, 2001-2002). In contrast to its predecessors, the real plan recognized that price freezes alone would not slow inflation to acceptable levels because fiscal profligacy on the part of government contributed to inflationary pressure. The plan thus began with a series of measures aimed at bringing a greater degree of fiscal management to the central government, reducing revenue transfers to subnational governments and freeing portions of the revenue pool to budgetary discretion. 
Establishing some centralized control of government spending was no easy task. The 1988 constitution reorganized Brazil's federalist arrangement, redividing the national tax base to increase revenue transfers to subnational governments, but failing to transfer a commensurate portion of federal programs to the state and local levels (Affonso and Silva, 1995).

Consequently, the central government was left with more mandated spending than revenue, leading to a chronic deficit, further exacerbated by the clientelistic practices of sub-national actors $^{8}$ (Fleischer, 1998). During the first stage of the real plan, with Itamar Franco in office, in order to reign in profligate spending, a constitutional amendment was passed creating the Fundo Social de Emergência (FSE). This fund de-linked 20\% of a large portion of federal revenues ${ }^{9}$ from constitutionally-mandated spending, granting the government the leeway to establish a budgetary surplus. Although the FHC reform agenda identified the need for a permanent discretionary powers, gathering political support for such an act proved difficult, since subnational interests were at stake. Given the complicated nature of support for the measure, the FSE emerged as a temporary act, needing re-approval, a characteristic that would provide opponents of re-centralization with bargaining power in the reform process (Samuels, 2003). With this new control over spending, the central government produced a balanced primary budget for 1994, establishing the first component of its stability plan: fiscal austerity.

The next step in the real plan began in March 1994, with the introduction of an indexed currency — the real unit of value (URV). The URV sought to synchronize price readjustment by taking into account the average of three price indexes. The conversion of salaries, rents, and public tariffs into the URV required adherence to some rules and obligations, while other prices

\footnotetext{
${ }^{8}$ In the transition to democracy, demands for patronage by state and municipal politicians amplified, contributing to a pervasive culture of clientelistic relations (Weyland, 1997-1998).

${ }^{9}$ The FSE applied only to shared tax revenues, of which the two largest sources are the Income Tax (IR) and the Industrial Products Tax (IPI). For more see, Afonso, J.R. and Serra, J. (2007).
} 
were free to use the old currency or the new. In sum, this stage sought to link prices all over the economy, equilibrating prices relative to one another while inflation still occurred in the old currency.

Eventually, after four months of this price adjustment process, the URV was transformed into the real, which converted at a one-to-one basis to the U.S. dollar. In this way, the plan successfully coordinated the synchronization of prices throughout the Brazilian economy and tied the stability of those prices to the U.S. dollar ${ }^{10}$. In other words, domestic price stability in Brazil became dependant on external markets, especially in the U.S. The strategy embodied in the real plan thus attributes two important characteristics to monetary policy and, as we shall see, to development policies in general. First, price stability became tied to the government's ability to maintain the value of the real relative to the dollar, which resulted in the overvaluation of the currency and created a greater need by the monetary authorities for foreign currency. Second, as a result of the focus on maintaining the value of the currency, the government needed to attract vast amounts of foreign investment, putting pressure on domestic interest rates.

The maintenance of the quasi-fixed currency regime - the foundation of ongoing price stability—required the government to maintain an open financial system and led to a dependency on foreign capital (Ferrari-Filho and Paula, 2003). In order to maintain the targeted minimum exchange value against the dollar, the government needed a large pool of foreign reserves to counteract market forces. The opening of trade and privatization ${ }^{11}$ —meant to increase international competitiveness - had short-term degenerative effects on the countries export

\footnotetext{
${ }^{10}$ Conversion to the Real began in July of 1994, with the new currency exchanging at a 1to1 basis with the U.S. Dollar. It should be noted that, though one of parity, this conversion rate was less rigid than the convertibility program adopted in neighboring Argentina. By the end of 1994, the Real exchanged at a rate of R\$ .85 to US\$1. See Macedo (2003).

${ }^{11}$ See section on government role in industrial development
} 
capacity, leading to a trade deficit. The legacy of the external debt crisis having made its mark on foreign reserves ${ }^{12}$, the government had no option but to depend on international investors for their liquidity needs. Thus the central bank maintained high domestic interest rates to increase the attractiveness of investing in Brazil. This resulted in a current account deficit and an overvalued currency.

The near immediate success of the real plan in reducing and controlling inflation is undeniable. Ferrari and Paula (2003) show a sharp division in inflation rates during 1994. The first half of the year experienced an accumulated inflation rate of $763 \%$, while the second six months exhibited a huge drop in inflation down to $38 \%$, clearly the result of the stabilization plan. Yet, in spite of this significant reduction in inflation, Brazilian price levels still rose faster than those in the U.S., the new anchor of Brazilian price stability. Given a residual inflation of 17\% (Macedo, 2003), the real experienced further overvaluation in comparison to the dollar. The success of reigning in inflation also brought other, more tangible, benefits. Barros (2000), for example, shows that absolute poverty levels between the years 1993 and 1995 dropped from $41.7 \%$ to $33.9 \%$, an effect attributed to rise in real incomes that occurs with a decline in inflation (Amann and Baer, 2002). Furthermore, the containment of inflation, alongside the central government's increased control of total government revenues, also had the bonus of exposing unsustainable government spending ${ }^{13}$, especially on the sub-national level (Samuels, 2003). With price stability a clear priority, establishing fiscal austerity at all levels of government presided as a fundamental objective. Key efforts to putting the brakes on fiscal

\footnotetext{
${ }^{12}$ With dismal growth and a lack of willing foreign investors, Brazil's foreign reserves collapsed in the 80s, resulting in a unilateral moratorium on debt in 1987.

13 This is referred to as the "reverse Olivera-Tanzi effect", which argues that because government spending is set in nominal prices and taxes indexed to inflation, a hidden public deficit is revealed in the absence of excessive inflation. See Bacha (1994).
} 
profligacy occurred through legislative channels. As already mentioned, the FSE played a key part in reducing government deficit spending to prevent the budgetary disaster looming behind the veil of hyper-inflation. However, the FSE required legislative renewal ${ }^{14}$ and only provided the central government with limited discretionary power, rather than erecting strict budgetary constraints. In 1995, congress passed the “Camata Law”, which required states to limit their payrolls to $60 \%$ of net receipts by January of $1999^{15}$. In addition to this, the refinancing of state debts required them to cease issuing bonds and, in 1998, the National Monetary Council prohibited sub-national actors from contracting foreign debt (Samuels, 2003). Finally, in 2000, the government passed the "Fiscal Responsibility Law", which set debt limits for all levels of government, stopped the central government refinancing of sub-national debts, and sought to increase fiscal transparency by requiring governments to publish revenue and expenditures. Moreover, it made misuse of public funds a felony crime with severe consequences: a direct effort to confront the culture of corruption.

A restructuring of the national financial system accompanied the drive to establish rules for government spending. Bank consolidation, both public and private, played a central part in this process. The Brazilian Central Bank (2006) reports that, especially in the initial stage of the Cardoso presidency, the number of state-owned banks decreased dramatically: from 32, in 1995, to 15 , in 2002. Private banks also decreased in numbers, while also becoming increasingly foreign owned. ${ }^{16}$ The reduction and consolidation of bank ownership came as an effect of the

\footnotetext{
${ }^{14}$ The FSE is not a permanent institutional reform, but a "sunset provision", requiring reapproval by congress. Samuels (2003) notes that drumming up political support for this reapproval necessitated trade-offs with sub-national actors, mostly in regards to restructuring their debt.

${ }^{15}$ Samuels (2003) reports that, previous to this, many sub-national governments maintained payrolls amounting to 80-90 percent of total revenue.

${ }^{16}$ Foreign private ownership rose by $20 \%$
} 
real plan, at the loss of inflation-generated profits and the exposure of untenable state debts in the absence of inflation (Almeida and Jayme Jr., 2008).

The consolidation of the financial system received direct support from the central government through the Incentive Program for the Restructuring of and Strengthening of the National Financial System (PROER) and the Program of Incentives to Reduce the Presence of the State Public Sector in Banking Activity (PROES). Consolidation, elimination, and privatization of state-owned banks occurred in conjunction with the process of reconciling the government budgets at the sub-national level. With state and municipal debts exposed, subnational governments had little choice but to negotiate with the central government to refinance their debts. In exchange for control over state-banks, the central government absorbed subnational debts, contributing to the ironic expansion of debt during an administration with the primary objective of combating the instability caused by a debt crisis.

Even with the efforts to reign in spending and consolidate the state banking system, a budgetary deficit plagued much of the Cardoso period. While a primary surplus of $5.2 \%$ was reached in 1994, the next four years failed to see even a primary balance. ${ }^{17}$ Though the struggle to institutionalize fiscal austerity played a central role in the political process, a balanced budget reappeared only when government revenues increased, and this a result of a rise in the tax rate. Given the maintenance of high real interest rates ${ }^{18}$ to attract foreign investment, interest payments on public debt exacerbated government accounting, driving the country into further

\footnotetext{
${ }^{17}$ According to the Central Bank of Brazil primary government expenditures for all levels of government resulted in a surplus of $0.3 \%$ of GDP in 1995; -.01\% in 1996; -1.0\% in 1997; and $0.0 \%$ in 1998 ,

${ }^{18}$ From 1994-2002, the average annual cost of interest payments on public debt as a portion of GDP was $9.99 \%$.
} 
debt. Samuels(2003) notes that $\mathrm{R} \$ 109.4$ billion of the debt accrued during the Cardoso presidency came as the direct result of the high-interest rates characterizing the period.

The process of bank re-structuring and sub-national debt refinancing contributed greatly to the accumulation of internal public debt. According to the Ministerio da Fazenda (2003), Brazil’s 1994 internal debt of R $\$ 60.7$ billion, or 28.1 per cent of GDP, grew by an order of magnitude to $\mathrm{R} \$ 623.2$ billion, or 55 per cent of GDP, by the end of 2002. $\mathrm{R} \$ 297.7$ billion of this indebtedness came through the restructuring of sub-national accounts. Samuels (2003) finds the structure of the internal debt potentially problematic due to the short terms of bond maturity, the debt's ties to the US dollar, and the sizeable portion of debt linked to Brazil's high interest rate. These factors forced Brazil to continuously to rollover debts that further increased public exposure to liquidity crises and would amplify the volume of debt in the case of a currency depreciation.

The negative effects of an overvalued real eventually forced the government to abandon its quasi-fixed currency regime. With foreign reserves in high demand-in order to finance an expanding debt, maintain the value of the currency, and pay for the trade deficit—Brazil's chronic and growing current account deficit left the country exposed to an international crisis. The Asian crisis of 1997, followed by the Russian crisis of 1998, brought speculative attacks against Brazil. In the midst of a run for re-election, the Cardoso administration responded to the attacks with conservative measures, raising interests and cutting spending. However, the deterioration of the external capital account ${ }^{19}$ proved too much. After re-election, the government finally acknowledge the overvalued real, allowing the currency to float. The devaluation, which many found to be long overdue, further contributed to the expansion of debt,

${ }^{19}$ Between September and December 1998 alone, foreign reserves plummeted by 38\% (FerraiFilho and Paula, 2003) 
but also alleviated the stagnation of growth and poor performance of the Brazilian export sector, both results of currency overvaluation. However, despite the many issues with macroeconomic model, the fixed exchange regime constituted the only element of monetary policy to change. While this did provide the possibility for lower interest rates, maintaining high real interest rates remained a key strategy to preventing price inflation, reaffirming Brazil’s dependency on foreign capital and tying the government in what Samuels (2003) calls a "fiscal straitjacket".

\section{Economic Growth and Development}

Following the course set by the Collor de Mello administration, FHC pursued a reform of state-economy relations with a less active role for government. In contrast to the traditional ISI model, the government endorsed a liberalized trading scheme, privatized state-owned companies, and sought to decrease its role as economic entrepreneur. In principle, these efforts can be understood as a modernization of the Brazilian economy—the same objective as the old development state. Yet the path to modernization has clearly changed, with increased global exposure acting as the catalyst for Brazilian economic development. Seemingly in contrast with the short-termed priorities of monetary and fiscal policy, the FHC government adopted a longterm development strategy with major immediate repercussions.

In general, trade policy during the Cardoso years followed the principle of liberalization initiated by the Collor administration. Most major trade barriers, both tariff and non-tariff, were removed during the first half of the 90s. By 1994, average tariff levels rested at $14.2 \%$, less than half of the nominal average at the start of 1990 (Baumann, 2001). Though the FHC government generally maintained a liberal trade policy, the over-valued real and a reduction in domestic producer protections led to a greater demand for imports and a decrease in exports, creating an increasingly worrisome trade deficit. In response to this, the government intervened in key 
sectors, such as the automobile industry, protecting favored industries from competition. This raised the overall tariff rate by 3\% (Baumann and Franco, 2006). The willingness of the government to intervene in this way suggests that, rather than a commitment to "free trade", the FHC administration demonstrated its priority for export competitiveness. The threshold for negative short-term results highlights the relative pragmatism of the government's long-term strategy.

State ownership and monopolies, a cornerstone of the old developmental state, also underwent continued dismantling during the Cardoso period. Again, continuing with the process started under the Collor government, the retraction of state controlled production continued under the auspices of reducing government debt and increasing productive efficiency. Because national control of industries was protected by the 1988 constitution, privatizing national industries and public utilities and breaking up monopolies required a constitutional amendment. Embedded in the broader efforts to reinstitute economic order, these legislative measures broke up state monopolies on telecommunications, subsoil resources, electricity, coastal shipping, and gas distribution. Petrobrás, the enormous and iconic national oil company, lost its monopoly on petroleum exploration and production. ${ }^{20}$ Reflecting the greater value placed on productivity, the removal of barriers to previously state-controlled industries served to create a more inviting atmosphere for foreign capital and ownership.

In addition to dismantling state monopolies, the FHC government also furthered the retraction of state ownership. Although the restructuring of ownership was extensive and affected major sectors of the Brazilian economy, the state often maintained partial, or even a majority stake in companies. Anuatti-Neto et al. (2003) divide the privatization process into three

\footnotetext{
${ }^{20}$ For an account of the general reform agenda, see Fleischer (1998).
} 
parts: first, the federal National Program of 'Destatization” (NPD), begun in 1991, focused on major national industries, such as Embraer and Companhia Vale do Rio Doce; the second, which primarily included state level privatizations, focused on utility providers; and the third, occurring during the Cardoso years, concentrated on the telecommunications sector. From 1990 to 2000, the number of State Owned Enterprises (SOE) dropped from 186 to 102. The proceedings from this privatization process provided the federal government with an extra $\$ 87$ billion in revenue, plus an additional \$18 billion in debt transfers. Between 1997 and 1998, the peak years of the so named "telecom program", receipts from the sale of SOEs accounted for 67 percent of the total value of the privatization process up to 2001. Yet, although the structure of ownership changed, the state most certainly did not abandon its activity in the economy entirely.

Rather than a wholesale retreat from its entrepreneurial role, the program of privatization and the removal of state monopolies can be seen as an increase in the partnership between government and the private sector. Many companies were not sold outright; rather, portions of the firms were made public, with the state maintaining a minority or even controlling stake. Rabelo and Vasconcelos (2002) describe the differing characteristics of the privatization process as it occurred in various sectors. While the petrochemical industry generally came under the increased influence of national groups, privatization in the steel sector, and especially the telecom sector, brought an increasing amount of foreign investment into the structure of ownership. In a study on leading companies in Brazil, Rocha and Kupfer (2002) note that, during the period 1991-1999, the market share of SOEs fell from 44.6 per cent to 24.3 per cent, that of multinational enterprises rose from 14.8 per cent to 36.4 percent, with private national enterprises maintaining their share of market sales. Thus, the structure of ownership in Brazil, while not fully privatized, became much more internationalized, especially in the telecom and 
energy sectors (Rabelo and Vasconcelos, 2002). However, it should also be noted that public utility companies were transferred to the private sector in the form of temporary concessions, with a reevaluation at the end of the designated period (Amann and Baer, 2009). This further suggests that, rather than assuming a hands-off approach, the state abandoned direct productive control embracing instead a more regulatory and managerial role in economic affairs.

The process of economic restructuring also entailed a smaller role for government in investment. With efforts toward fiscal austerity pivotal to the government's primary objective, it comes as no surprise that state investment in infrastructure and economic development continued to decline through the 90s. According to the World Bank (2007), public investment in infrastructure fell from an average of 5.22 per cent of GDP during 1981 to 1985, to 2.35 per cent of GDP in 1996 to 2000. At the same time, Foreign Direct Investment (FDI) increased substantially. Data from the Brazilian Central Bank reveals that gross FDI increased from \$2 billion in 1994 to $\$ 16.7$ billion in 2002, with the year 2000 showing the most highest level at $\$ 32.8$ billion. Despite the fact that a great portion of this influx in FDI can be attributed to the privatization program, the trend of increased private investment, both portfolio ${ }^{21}$ and FDI, and the decreases in government investment suggest a new reliance on private capital, and especially foreign capital, to drive Brazilian investments.

The focus on price stability brought little growth, accompanied by a negative trend in employment. Following IBGE data, the Brazilian economy during Cardoso period was characterized by an average growth rate of $2.3 \%$, with zero growth in 1998 . A comparison of growth during the 90s with that of the preceding "lost decade" reveals an even more startling

\footnotetext{
${ }^{21}$ While FDI increased steadily, portfolio investment fluctuated through the 1990s, albeit at high levels relative to the past. While 1994 registered a massive \$54 billion in net foreign portfolio investment, the same figure fell to \$872 million in 2001.
} 
statistic: while the 80 s produced an average of 3.03\% growth per annum, the reform dominated 90s delivered a mere $1.82 \%$ growth average. Coinciding with the dismal growth record, open unemployment rose from 5.1 per cent in 1994 to 7.6 per cent in 1999. Yet, citing a study by the DIEESE, Amann and Baer (2002) signal to the inaccuracy of official figures, due to "disguised unemployment”, and assert that total unemployment in 2000 was $16.2 \%$ of the labor force. In general, these same authors attribute increased unemployment to the shedding of "excess labor" brought on by the privatization process, as well as increases realized in productive technology resultant from increased trade openness. Along with this came a rise in the informal sector, parts of which later became reintegrated into the formal work sector through a change in tax laws (Macedo, 2003) ${ }^{22}$. Given the dismal growth of the economy, and especially of employment—due in great part to the preference for capital-intensive productivity gains-an even greater need to strengthen the social welfare system arose.

\section{Social Policies-FHC}

In the past, efforts to raise and protect the social well-being concentrated in the formal channels of representation, especially social security and medical benefits. The 1988 constitution endorsed social inclusion as a basic right of citizens and furthermore lent its decentralized bias to the social service provisions it engendered. Given the longstanding inequality in Brazil, the increase in informal employment, the culture of clientelistic practices, and the influence of arguments for more efficient governance, new strategies to alleviate poverty and raise the standard of living became necessary. Traditional systems of social protection were becoming too costly, as with social security, and some of the newly expanded and constitutionally mandated services, such as those addressing education and health, received too little funding. In response

\footnotetext{
22 The author notes that a 1999 simplification of taxes for small and micro firms encouraged formalization of labor contracts.
} 
to the growing need of society and the inefficacy of the old system, reforms and new welfare institutions emerged during the FHC government, contributing to the further evolution of the Brazilian government's role in societal development and well-being.

Income transfers proved fundamental to the FHC social development strategy. Central to the government's reformist efforts, reconstructing the national pension system constituted a major objective in the broader context of redistribution. Brazil's national pension system began to show signs of trouble in the late 80s, with the slowdown of job creation and the inclusion of rural workers in the social security system. Add to this increases in life expectancy, the demographic shift to an aging society, and the effects of the real plan on the real value of benefits and what emerges is a fiscal imbalance. Furthermore, the government passed a new minimum wage in 1996 and, given that a large portion of benefits are tied to the minimum wage, this contributed to the rising costs of the pension system. By 1998, social security expenditures reached 10 per cent of GDP, being disbursed to nearly 19 million real beneficiaries and producing a deficit equal to 3 percent of GDP (Baumann, 2001). Between the three components of the national pension system ${ }^{23}$, public sector employees received 75 percent of the benefits paid out, though they represented a significantly smaller number of actual beneficiaries. A partial reform of the pension system was carried out in 1998. As the deficit of the system coincided with the government's larger agenda, this reform focused primarily on reducing expenditures (Fleischer, 1998). This it accomplished through installing a cap on monthly benefits (with special treatment for the public sector), supplanting qualification by minimum time of contribution for one according to minimum time of service, eliminating early

\footnotetext{
${ }^{23}$ These are: 1) a general, mandatory, publicly managed, pay-as-you-go scheme for private sector workers, 2) special schemes civil servants, and 3) optional, privately managed supplementary schemes for private sector workers (Bonturi, 2002).
} 
retirement benefits and incentives, and making room for the introduction of a new benefit calculus that removed incentives for income under-reporting (Giambiagi and Ronci, 2005). However, many of the most egregious elements of the civil servant social security system remained unchallenged, likely due to the fact that the legislators themselves were beneficiaries of systemic biases.

Alongside the efforts to balance pension expenditures and contributions, the FHC government created new social welfare institutions, with the object of raising the basic standard of living. As the efforts at fiscal restraints provided an obstacle for large increases in social investment and welfare spending, the FHC government sought to improve public social services through increased institutional efficiency (Faria, 2002). To this end, the administration adopted some fifty programs. Amongst these, income transfer programs, such as Bolsa Escola, Bolsa Alimentação, The Rural Worker’s Pension, and the Disabilities Benefit program proved enormously successful. By 2002, income transfers reached a total of R 27 billion, or about 2.5 per cent of GDP. Macedo (2003) notes the coincidence of these programs with the IFI supported objective of targeted social programs, drawing further attention to the fact that the most “successful” programs address the needs of extremely vulnerable populations.

The increasing role of income transfer programs exhibited two main trends: inclusion of exposed and vulnerable populations, and the use of income transfers as incentives. The Rural Worker's pension and the Disabilities Benefit exemplify the further realization of the inclusion model enshrined in the 1988 constitution and the gradual evolution of Brazil's social welfare system toward universality. Reaching 6,370, 547 workers and costing R 15.5 billion, the Rural Worker's pension, which accounted for 33.2 per cent of total income transfers in 2001, reflects the steady expansion of social protection throughout the 90s, despite efforts at austerity (Bonturi, 
2002). The social security system also expanded to include benefits for disabled and elderly people, irregardless of past contributions. Initiated in 1996, this program came to benefit 2.2 million people in 2002.

Within the evolving social protection system, the increased use of Conditional Cash Transfer (CCT) registers as particularly noteworthy. Coinciding with the advice of international agencies, such the World Bank, the IMF, and UNICEF, many of the Cardoso administrations most widely praised social programs reflected the targeting, empowering, and co-responsibility priorities of the "New Social Policy”24. Bolsa Escola, Auxilílio Gás, and Cartão Alimentação are all programs operating off the same basic principle: in exchange for immediate aid, beneficiaries must participate in longer term strategies for poverty relief, such as ensuring school attendance, receiving vaccinations, or attending informational workshops on nutrition. Draibe (2005) notes that this expanding and CCT-led strategy for poverty relief became further supported with the creation of the Poverty Fund, in 2000, a law pushed through by the PT.

Educational spending received a notable level attention during the FHC years. Aside from the attendance increasing effects of the Bolsa Escola scholarship program, the FHC government also attempted to ameliorate school funding issues through the creation of FUNDEF. The 1988 constitution mandated minimum portions of budgets at all levels of government to be set aside for financing education. However, the budget crises plaguing many sub-national governments produced spending shortfalls in this crucial area, especially in poorer regions of the country (Afonso and Mello, 2000). In 1998, the federal government responded by creating FUNDEF, a fund to ensure the minimum amount of spending per child in school. The fund was created as a temporary constitutional amendment, needing re-approval in 2006. In addition to

\footnotetext{
${ }^{24}$ For a full discussion on the emergence and character of the new approach to welfare policy in the context of the neoliberal policymaking environment, see Molyneux (2008).
} 
earmarking 15 percent of total revenue transfers and ICMS collection for financing basic education, this program also set aside resources to enhance the qualifications of teachers.

As with other social provisions, the 1988 constitution expanded health services by establishing access as a universal entitlement, coordinated by a single public entity: the Integrated Health System (SUS). Efforts to finance health services encountered similar challenges as other social programs in the 90s. The government took measures to reinforce the financial base of health services in 1996, with the creation of a new, specific tax, and again in 2000, through a constitutional amendment that mandated a 17 percent of income minimum expenditure level for sub-national governments (Draibe, 2005). In addition to this, the Family Health Program (PSF) was created in 1998. This program sought to improve distribution of health services by decentralizing services. In lieu of urban-centered medical facilities, teams of health service professionals were created to engage on the community level, bringing greater access to rural areas ${ }^{25}$. Efforts to decrease the price of pharmaceuticals also benefited national healthcare services. Citing Almeida (2002), Macedo (2003) notes the dramatic increase in generic, less expensive drugs, from an estimated 4.6 million boxes in 2000, to approximately 71.5 million in 2002.

In general, governance during the Cardoso presidency resulted in gains for most social indicators. The number of people living in impoverished circumstances dropped considerably, from 41.7 percent in 1993, to 34 percent in $2002^{26}$. However, as no significant changes occurred between 1995 and 2002, the majority of this reduction in poverty can be seen as a positive effect of the price stability realized by the real plan. Inequality, as measured by the Gini index, stayed relatively the same-a surprising outcome given the increase in unemployment from 6.1 percent

\footnotetext{
${ }^{25}$ For a detailed discussion about the PSF, see Rocha and Soares (2009).

${ }^{26}$ According to IPEA data.
} 
in 1995, to 9.4 percent in 2001. At the same time, enrollment in primary school continued to increase, infant mortality and illiteracy rates continued to decline, health services expanded to cover more people, and access to basic utilities increased ${ }^{27}$. All of this information indicates that, while state reforms do appear to have produced negative effects in areas such as labor and income, the gradually increasing role of government in providing social services seems to have had positive effects in increases in the overall standard of living.

\section{Lula-A Radical's Agenda}

Brazil, like many of its South American neighbors, responded to the failure of the Washington Consensus by voting the left into power. As the 1990s came to a close, it became clear to many that the privatizations, austerity measures, and retraction of state influence taking place as part of a neoliberal reform agenda had, at best, limited success. Lula, the Worker Party's (PT) perennial candidate, represented a shift in policy-making toward more socially oriented governance. Even though the PT had opposed neoliberal reforms in the 90s, party leaders recognized the necessity of support from the Brazilian business community and from investors abroad, leading it to adopt a pragmatic perspective on economic policy.

In 2003, when Lula's electoral victory became imminent, the potential threat of Brazil’s socialist party gaining power led international investors to bet against Brazil, negatively affecting the country's foreign reserves, inflation rate, currency value, and interest rates. Falling in line with the recommendations of the IMF, President Lula promised to respect the principles of market stability and openness embodied in the reforms of the preceding decade and ameliorated this tension. Thus the priority for short-term stability established a place of primacy in the government's agenda due to the pressure of the international financial community. Lula's

\footnotetext{
${ }^{27}$ For a rundown on social indicators during the Cardoso period, see Macedo (2005).
} 
mandate then was two-fold: maintain conditions favorable for foreign investment and improve the social well being of the nation.

The Lula administration's policy agenda clearly reflected the double mandate that brought it to power. While the new government acknowledged its dependency on global investment and competitiveness to drive national development and economic growth, this appeared to coincide with a return to the federal government taking a more decisive role to make economic growth produce more socially tenable results. In the Plano Plurianual de Ação (PPA) 2004-2007, the administration clearly articulated its development goals and strategies. The government declared its meta objectives as: 1) social inclusion and the reduction of social inequality, 2) economic growth generating job creation, income growth, environmental sustainability, and the reduction of inequality, and 3) the promotion and expansion of citizenry and the strengthening of democracy (PPA, 2004). In essence, the government proclaimed that it would cure the poor growth, unemployment, and socially polarizing effects of the previous two decades, ushering in a new model of development for Brazil.

With macroeconomic policy locked into place at the behest of international financiers, the administration moved to distinguish its development strategy from those of former governments by consolidating and expanding social welfare programs. While these effort had the clear intention of alleviating the widespread immiseration of poverty, and in particular, hunger, the government also noted the eradication of poverty as fundamental block in its economic development strategy. To this end, the PPA predicts that increases in mass consumption would bolster its efforts to spur economic growth. In summation, the Lula administration identified social development as the core dimension of its development strategy.

\section{Macroeconomic Management-Lula}


As previously mentioned, Lula's ascendancy to the executive office initially troubled foreign investors. Worries that the PT government would alter or abandon the investmentfriendly macroeconomic model of the Cardoso administration led to a speculative attack, which necessitated an IMF intervention. From the negotiations surrounding this event emerged an agreement that Brazil's forthcoming president, whomever that should be, would continue to follow the economic management scheme of the departing administration. Hence, at least in the area of monetary policymaking, the Lula administration's options were clearly limited.

With stability preordained as a requisite concern for the new government, monetary policy continued its conservative path. 1999's monumental currency devaluation marked a change in exchange rate policy, but the central bank continued to target inflation levels through the manipulation of domestic interest rates, thus bringing about a revaluation of the real. Barbosa-Filho (2008) notes that authorities remained committed to this tactic, continuing to adjust interest rates up or down, depending on the circumstances. With domestic inflation and uncertainty in the international capital markets contextualizing the political transition, Lula's first year in office was marked by an increase in base interest rates, from $18 \%$ in September 2002, to 26.5\% in February 2003. Over the course of Lula's first term in office, this strategy produced an average real base interest rate of $11.3 \%$, even higher than that of the preceding administration. In addition to this, the real experienced an increase in its exchange value relative to the dollar, though this did not bring negative effects to Brazil's trade account. ${ }^{28}$ The central bank's strategy

\footnotetext{
${ }^{28}$ International markets for Brazilian exports, especially primary and agricultural goods, contributed to a strong performance of Brazilian exports during a majority of the Lula presidency.
} 
experienced great success with respect to controlling inflation ${ }^{29}$, accompanied by a staggered, yet steady, reduction in real interest rates.

Fiscal policy during the first Lula administration followed a mostly conservative path. An increase to the primary budget surplus target, from $3.5 \%$ of GDP to $4.25 \%$, marked Lula's first year in office. This conservative move brought the predictable result of putting pressure on government expenditures, especially in the area of social services and public investment. While this fiscal crunch can be seen as a direct result of the higher cost of servicing debt, a bi-product of monetary policy, it did not last long. Increased revenues made possible both the higher budgetary surplus and increased spending in favor of the poverty relief agenda of the PT. Increases in the primary budget surplus served to lower the debt to GDP ratio to a level favorable to international creditors, namely, under 50\%. This controversial strategy ostensibly places priority on the long term objective of a reduced debt burden, while creating an immediate impact on the government's short term budgeting options. In practice, over the course of Lula's two presidencies, total debt has indeed dropped, from 60.5\% of GDP at the beginning of 2003 to 41.7\% by July of 2010 (IPEA, 2010). ${ }^{30}$ The reduction in debt levels eventually made more fiscal space for some of the government's spending priorities, as well as slight reduction in the budget surplus target. Some analysts have further critiqued the priority placed on debt servicing as a move to conform to the desires of investors, which eventually brought the desired result of an improved credit rating (Pereira, 2009). This higher investment grade brought a further increase in the role of international capital in Brazil, to such an extent that the government reinstituted a tax on capital entering and leaving the country, hoping to deter those seeking only a quick return.

\footnotetext{
${ }^{29}$ IPEA data reports that inflation levels after 2003 show that inflation did not exceed 6\%.

30 Among debts repaid in this period, Brazil’s 1996 \$15.5 billion payback to the IMF deserves special note, given its political connotations.
} 
Tax reform constituted a major objective of the first Lula presidency and further aided the effort to increase spending while remaining within the increased budgetary constrictions. Occurring within the context of the historical struggle between the central government and subnational governments over revenue sharing, the Lula administration met with governors and other sub-national politicians to form a proposal for tax reform that would reflect the interests of all levels of government. After rounds of negotiations and political concessions, government officials emerged with a bill containing far less of the bold tax system consolidation measures than originally proposed. It was, however, recognized as containing one major innovation: the PIS-Cofins, two taxes contributing to fund Social Security and social inclusion programs, became non-cumulative $^{31}$. Though the change was thought to have a negligible effect on revenue, Barbosa-Filho (2008) notes that, along with increased revenues due to higher growth rates, the new, non-cumulative character of these important taxes realized a $0.5 \%$ of GDP increase in the total contributions. Thus, while the monetary climate placed constraints on fiscal policy, the Lula government managed to increase social spending through an increase in taxes. Later, in Lula's second term, a new focus on economic growth led the government to initiate tax cuts, mostly through investment incentives.

The second Lula administration brought a clear shift to fiscal policy making. Loureiro, Gomide, and Santos (2009) argue that the administrative and staff changes brought on by the 2005 corruption scandal marked a turn in priorities toward growth ${ }^{32}$. With Brazil continuing to show relatively disappointing growth figures, it became clear that fiscal austerity as a long-term debt reduction strategy posed an obstacle to economic development. With this realization came a

\footnotetext{
${ }^{31}$ For a full discussion on the 2004 tax reform effort, see Wernick (2006).

32 This included, most notably, the replacement of Finance Minister Antonio Palocci with Guido Mantega.
} 
revitalization of the government's role as a an investor in the economy. Although the conservative policy making of the Central Bank continued, albeit increasingly more favorable to investment given international conditions ${ }^{33}$, the central government actively engaged itself in increasing investment, in order to "unthaw" the economy. The National Economic and Social Development Bank (BNDES) and Caixa Econômica Federal both received increased funding as part of the government's Growth Acceleration Program (PAC), launched in 2007. Realizing that economic growth would not alleviate budgeting issues, aid the administration's social welfare priority, and furthermore abate much of the criticism laid against it, the Lula government made fomenting growth a new pillar of the macroeconomic strategy.

\section{Economic Growth and Development-Lula}

Rhetorically, promoting economic growth constitutes a key element of the Lula administration's priorities from the very beginning. Though this objective received some attention in the PPA, the priority placed on monetary stability and the reduction of the debt to GDP ratio precluded any increase in government investment. In this respect, the second Lula administration represents a truer manifestation of the vision offered by the PT in the documents defining its objectives ${ }^{34}$. With the announcement of the PAC, the Brazilian government began to behave in a manner more reminiscent of the developmental policies of the past.

The increased level of fiscal austerity occurring during Lula's first presidency prevented the government from counter-balancing the dearth of investment characterizing Brazil since the beginning of State reforms. However, that is not to say that the government did not take measures to reinvigorate its role as a promoter in the economic system. The Lula administration

\footnotetext{
${ }^{33}$ That is, both low international interest rates, largely because of actions taken by the U.S. central Bank, and a strong demand for Brazilian exports, which created a trade account surplus. ${ }^{34}$ Such as, "Another Brazil is Possible", Lula's "Letter to the Brazilian People”, and the PPA. For a discussion on these, see Gomide, Loureiro, and Santos (2009).
} 
defined its approach to economic development through the unveiling of its Industrial, Technological, and Foreign Trade Policy (PITCE), a multi-agency policy agenda. As the title suggests, this agenda focuses on improving Brazil's productive and technological capacity to gain an improved and more competitive position in the international marketplace. More precisely, this agenda embodies an attempt to assert the state's role in increasing the systemic competitiveness of the Brazilian economy through promoting a National System of Innovation $(\mathrm{NSI})^{35}$. In describing the nature and specific actions taken toward this new objective, Doctor (2009) identifies three main policy areas: (i) improving the competitiveness of existing industries through modernization; (ii) creating incentives and institutional support in four key sectors: software, semi-conductors, capital goods, and pharmaceuticals; and (iii) promoting futureoriented technologies, such as biotechnology, renewable energy, and nano-technology.

In contrast to traditional efforts to expand fiscal support of national industries, Brazil’s $21^{\text {st }}$ century industrial policy first sought to adjust government structure and behavior. New agencies emerged to change the process of development policy formation, as well as increase its success in implementation. The Council for Economic and Social Development (CDES), which provides business leaders and civil society a forum with government officials-including the president of the republic — formed in 2003, in hopes to define the Lula administration's distinct approach to policy ${ }^{36}$. In 2005, the creation of two new institutions, the Brazilian Industrial Development Agency (ABDI) and the National Industrial Development Council (CNDI), served to directly support the policy objectives set out in the PITCE, and later its successor: the

\footnotetext{
${ }^{35}$ In reality, the NSI strategy is not new to Brazil, as it closely resembles the National Scientific Technological Development System, initiated in the early 50's, but abandoned during the military dictatorship. See Furtado and Suzigan (2006) for a full discussion.

${ }^{36}$ Doctor (2006) notes that the CDES embodies Lula's “contract” with Brazilian people, reflecting the promises made in the "Letter to the Brazilian People".
} 
Production Development Plan (PDP), announced in 2008. While ABDI came to be in order to provide better coordination and institutional efficiency, ensuring the provision of means for policy ends, the CNDI supplied a direct forum for the private sector to offer its perspective on government action in promoting economic development.

Government efforts to revitalize industrial policy also included numerous legislative pieces. The Lei de Inovação, passed in 2004, essentially encouraged greater information and technology innovation and sharing by creating R\&D partnerships, establishing regulatory standards for technology transfers, and supplying common resources and equipment to ensure the means of innovation. In addition to this, the Lei do Bem, in 2005, created a variety of fiscal and tax incentives to encourage investment in technology; the Informatics Law extended fiscal incentives for the use of informatics in R\&D; and the Bio-Security Law created regulations for research with stem cells and genetically modified organisms. Finally, the government's commitment to promote cooperation as a pivotal element of development resulted in the PublicPrivate Partnership (PPP) law, passed in 2004, which served to reassert the government's dedication to working with the private sector on public projects.

Among other efforts to reactivate the state's role as promoter of economic development, a notable increase in development funding aided the PITCE and PDP objectives. In 2004, a new model of industrial fund management brought an increased level of efficiency to the use of financial resources located in the National Science and Technology Development Fund $(\text { FNDCT })^{37}$, a subprogram of the Financiadora de Estudos e Projetos (FINEP). The increase in resources distributed through FNDCT coincided with the more active role taken by FINEP as a whole. Likewise, BNDES showed a consistent and significant rise in lending. Disbursement of

${ }^{37}$ Total resources increased from R $\$ 343$ million in 2002, to $\$ 800$ million in 2005, for example (ABDI, 2008). 
funds expanded from $\mathrm{R} \$ 35.1$ billion in 2003, to R\$ 137.4 billion in 2009. Reflecting the targeting strategy set forth in policy, these loans were made to companies in strategic sectors, such pharmaceuticals, computer technology, and especially the energy sector.

The PAC, initiated in 2007, provided further rationale for state intervention. The fiscal austerity measures dominating policy making constraints levels of state investment. The launch of the PAC was a direct response to the lack of investment in Brazil, both private and public, especially in infrastructure. Over a period of four years, the PAC provided R $\$ 503.9$ billion for investment in energy, sanitation, transportation, housing, and water resources. Increasing investment in infrastructure had clear implications on improving the overall capacity of the Brazilian economy, but was further seen as a means of "unthawing” the economy, breaking Brazil out of its mediocre growth. In this respect, PAC seems to have realized some success. The Brazilian economy grew by 6.1\% in 2007 and 5.1\% in 2008, with 2009 exhibiting slightly negative growth ${ }^{38}$; however, with estimations for growth in 2010 at around $7 \%{ }^{39}$, it seems clear that the impact was minimal. Moreover, GDP per capita has continued on an impressive and steady rise since 2003, jumping from $\$ 6,970$ a person in 2003, to $\$ 8,220$ in 2009 .

International factors continued to influence the evolution of Brazilian political economy. As in previous years, the role of international investment continued to expand. The Brazilian Central Bank (2010) reports that net foreign portfolio investment (FPI) in Brazilian companies reached massive levels. While FPI measured $\$ 5.1$ billion in 2003, this figure reached $\$ 48.1$ billion in 2007 and $\$ 46$ billion in 2009. More importantly, FDI also increased, reaching it’s peak, at $\$ 45$ billion, in 2008. In sum, the value of FDI during the two Lula administrations up to 2009,

\footnotetext{
${ }^{38}$ The drop in growth in 2009 is generally recognized as the result of a global financial crisis, originating in the US. Data from the IBGE.

${ }^{39}$ Following reports from O Estado de São Paulo, 9/15/2010.
} 
registers as $\$ 167.7$ billion, $\$ 2$ billion more than the aggregate value of FDI during the Cardoso presidencies.

Brazil’s performance in the global market place was of pivotal concern. The Lula administration's industrial policy focused intently on the economy's ability to compete on the global level. In point of contrast to the former administration's strategy, this government sought to actively promote export industries, through programs such as the PITCE and the PDP. Moreover, Brazil’s past financial instability, resulting from a dependence on foreign capital, created a need for ensuring a surplus in the trade account. In Lula's first year in office, exports grew by $21.3 \%$, up from $3.7 \%$ growth in 2002. After six years of consistent and significant growth, the value of Brazil’s exports reached $\$ 197.9$ billion. More importantly, this growth outpaced the value of imports in every year, bring the total trade surplus over the period 20032009 to $\$ 240.4$ billion. ${ }^{40}$ However, the stellar performance of the export sector was largely pushed by the world demand for primary goods. While the returned focus on competitiveness does coincide with a major turn around in the trade account, the sectors targeted by the new industrial policy did not lead this accomplishment.

\section{Social Policy- Lula}

Much has been made by the Lula administration's focus on social policy, and with good warrant. Building off of the efforts of the preceding administration, government programs designed to fight poverty expanded not only in their reach, but more also in their effect, lifting masses of impoverished people to a higher standard of living. At the same time, innovations in the economic development model envisioned by the government called for a strengthening of mass consumption and recognized the dual impact of public infrastructural projects, tying

\footnotetext{
${ }^{40}$ My calculations according to SECEX/MDIC data.
} 
together arguments for social and economic intervention. Yet, as critics are quick to point out, key services, such as education and healthcare, continue to suffer a lack of funding. While it is clear that the government's role in promoting social welfare now takes an explicit route, this seems to be more the maturation of previous visions, rather than a breakthrough in establishing social safety nets.

The Lula administration pursued its vision of empowerment and inclusion by consolidating and expanding CCT programs. In 2003, Bolsa Escola, Bolsa Alimentação, and Auxilio Gás, were joined by Cartão Alimentação, a new food entitlement scheme using a special electronic card, under the umbrella program Fome Zero. Though unified in name, CCT programs suffered from a lack of administrative efficiency and overall co-ordination (Hall, 2008). In order to alleviate these issues, the government incorporated the CCT sub-programs ${ }^{41}$ into a single, unified scheme, labeled Bolsa Família. To further bolster the efficacy of the new, consolidated CCT, the Ministry of Food Security and Fight Against Hunger was merged with the Ministry of Social Welfare to form the Ministry of Social Development and Fight Against Hunger (MDS), which assumed management of the Bolsa Família program from the President’s office. However, while the centralization of management on the federal level is seen as contributing to the program’s achievements, Fenwick (2009) argues that the real source of success lies in the federal-municipal partnership, as distribution happens on the municipal level. Thus, while Bolsa Família receives much praise as a federal program, one must also note the growing role of municipalities and the benefits of decentralized distribution of services.

\footnotetext{
${ }^{41}$ The Programa de Erradicão do Trabalho Infantil (The Plan to Eradicate Child Labor, or PETI), a program initiated in 1996 and utilizing conditional cash transfers as an incentive to prevent child labor, was later folded into the Bolsa Família program, in 2006.
} 
Promises to mitigate poverty during the Lula administration proved substantive. In terms of reach, CCT programs have greatly extended the number of beneficiaries, from 6 million families in 2002, to 12.7 million $^{42}$ by the end of 2009 (MDS, 2010), making Bolsa Família the largest CCT program in the world. Moreover, benefits per household have increased as well. Between 2003-2005, the average of benefits per household nearly tripled from $\mathrm{R} \$ 28$ to $\mathrm{R} \$ 75$ per month (Brazil, 2005). By 2010, this average reached R\$95 per month, with the total cost of Bolsa Família reaching $0.8 \%$ of $\mathrm{GDP}^{43}$. And the expansion of income transfer programs brought results. The percentage of people living in poverty, defined as an annual income of less than $\mathrm{R} \$ 121$, dropped from 28\% in 2003 to $19 \%$ by 2006. As well, the infamous inequality plaguing Brazil, as measured by the IPEA's calculation of the Gini coefficient, saw an appreciable reduction, from 0.589 in 2002 to 0.543 in 2009.

The Lula administration took other actions that altered the welfare system. Most prominently, this included the passing of pension reform bill, in 2003, which served to compliment the 1998 amendment. As with the preceding reform, this amendment found its impetus in the still deteriorating fiscal situation of the national pension system. In contrast to its predecessor, the 2003 reform targeted the public sector regime. This included establishing a minimum retirement age for civil servants, unifying contribution rates, and placing a cap on benefits. And while these measures sought to decrease the growing expenditures of the system, changes made to social contributions taxes, the "PIS-Cofins", led to increased revenues. According to Barbosa-Filho (2008), this increased PIS-Cofins contributions by 0.5\% of GDP, a rise that went directly to increased income transfers.

\footnotetext{
${ }^{42}$ With the an average family size of 4 in Brazil, this means that approximately 50.8 million citizens benefit from Bolsa Família.

${ }^{43}$ This is up from $0.2 \%$ of GDP in 2003.
} 
Intervention in the labor market further characterized the Lula government. Throughout Lula's two terms, the government utilized the ability granted it by the 1988 constitution to reassess the minimum wage in Brazil. Given Lula’s personal history with the labor movement and his political constituency, it comes as no surprise that his presidency would be marked by consistent increases in Brazil’s minimum wage, from R $\$ 200$ in 2002 to $\mathrm{R} \$ 510$ by the start of 2010. These increases outpaced inflation, bringing real gains to the average worker's income. Baltar, et al (2010) note that annual increases in the minimum wage between 2003 and 2008 brought a total of $38.3 \%$ in real gains to base wages. Furthermore, the government's growing concern with economic growth, and its subsequent promise of increased revenues, may have aided in the growth of formal employment, which grew from 25 million in 1999 to 39.4 million in 2008 (Baltar, et al., 2010). While government efforts to create a more favorable environment for productive investment may or may not have been a factor in this growth, it is clear that the increase in public hiring has certainly contributed to increases in secure employment. According to the Annual Account of Social Information (RAIS), in the period 2003-2008, civil servants increased by $25 \%$, or 1.4 million employees. Much of this coincided with the government's reengagement with promoting growth, through the PAC.

The means employed to rekindle growth, through the PAC, coincide with the government's social policy agenda. In the PAC, infrastructural investment is seen not only as a route to increase the logistical capacity of the productive sector, but also as an instrument to universalize economic benefits. Of the $\mathrm{R} \$ 503.9$ billion set aside for the PAC, $\mathrm{R} \$ 274.8$ billion were earmarked for social and urban infrastructure. Projects within this area of investment sought to increase access to sanitation networks, create housing and urban transportation, and universalize access to electricity. These investments carried clear implications on the 
government's vision for social development, which placed inclusion and empowerment at the forefront, making access to the benefits of modernity an explicit public goal. With this, the government marks an apparent turn in its development strategy: economic growth and social welfare become interdependent factors, with the promotion of either producing benefits for the other..

One pressing critique of the Lula administration regards its lack of attention on the provision and quality of education and health services. With CCT programs assuming a central place in the government's agenda, many argue that badly needed funds were channeled from these pivotal services to poverty relief efforts. As a portion of federal spending, education decreased from $3.01 \%$ of the total budget in 2002, to $2.66 \%$ in 2009, with 2006 dedicating only $2.17 \%$ of the budget to education. Likewise, funds allocated to health services decreased from $5.79 \%$ to $4.55 \%$ of total federal expenditures. Over the same period of time, expenditure on social assistance increased from $1.48 \%$ to $3.01 \%$ of the budget ${ }^{44}$. Despite this relative fall in spending, some innovations were made in the area of education.

Amongst government efforts to advance the quality of public education, the extension of federal aid to under-funded school districts and the creation of a new teacher evaluation program emerge as noteworthy. Fundef, which established a minimum level of funding per student, nation-wide, expired in 2006. However, the program had garnered notable success, making it clear candidate for renewal. This occurred in 2007, with the program's name receiving a minor change to Fundeb ${ }^{45}$, and a new, 2020 expiration date. In addition to this, policy makers created incentives for increasing the technical capacity of schools, through the Professionalize Brazil

\footnotetext{
44 These figures represent my calculations according to IPEA data.

45 This stands for: O Fundo de Manutenção e Desenvolvimento da Educação Básica e de Valorização dos Profissionais da Educação, or the Fund for the Maintenance and Development of Basic Education and the Valorization of Educational Professionals.
} 
program $^{46}$, and increasing the partnership between educational professionals and the community, through the Formation of the School ${ }^{47}$ program. While these efforts pale in comparison to the attention given to poverty alleviation, they do offer two interesting points of intersection with the government's central objectives in that they: (i) encourage a more technologically capable and innovative society and (ii) utilizing private-public partnerships.

\section{A New, Postmodern Developmental State}

The combined experience of these two administrations defies the paradigmatic labels used to describe their character. This study has shown that, while both administrations have espoused policies that reflect a neoliberal purview, they have also behaved in ways that disregard orthodox recommendations and embraced other, heterodox positions. This suggests that policies have not been employed merely on the merit of their ideological underpinnings, as many analysts imply, but pragmatically, in reference to a specific goal. In comparing the old developmental state with the defining actions of the contemporary, in and after the reform process, we readily conclude that, throughout, the government has maintained its traditional motive purpose: promoting development. This implies that, rather than relinquishing development to supposedly natural forces, the government has actively pursued new methods of intervention to promote development, including reforming the modes of intervention themselves. What distinguishes the new from the old is not the retraction of government from economic and social affairs, but the increased use of orthodox theory in justifying government action.

Emergent from the period of institutional reform, then, is not the minimalist, free market state of ideologues on either side, but one employing a bricolage-like strategy of development policies. While the old development state represented a paragon of modernism—demonstrating

\footnotetext{
${ }^{46}$ Brasil Profissionalizado

${ }^{47}$ Formação pela Escola
} 
its preference for an industrial society; marked by order and a centralized, rationally based system of control—the new development state represents the postmodern. Rather than producing some very definite and cogent structure of governance, reforms reflected the changing nature of national politics and the increasing demands of globalized networks, making them responsive to changes in these factors. As policies continue to evolve and adapt to effectively promote the development of Brazil’s productive structure relative to other societies, new political circumstances have greatly impacted the way in which government has pursued this goal.

Just as the 1930 political revolution gave birth to the monolithic development state, the 1985 return of democracy marked the beginning of a more decentralized structure of governance. The tension between the central government and subnational politicians has carried enormous weight in policy making during both administrations. The drive for fiscal balance, led during the FHC government, entailed negotiations and compromise between levels of government. This process had as much to with fighting corruption and installing measures for transparency as it did with following orthodox economic prescriptions. It is precisely because these measures found multiple impetuses that they passed the test of an increasingly democratic political process and came to be. Likewise, the Lula administration acknowledged the necessity of negotiating with subnational politicians during the 2003 tax reform. While each administration engaged in this process for its own issues, the fact that power sharing between levels of government has become a vital factor in Brazil highlights an important point regarding the character of government in the postmodern period: in order to be effective, the state must reach consensus.

Other new, common political dynamics surge forth as important in defining the structure of government and determining its role in development. Throughout the time span under question, poverty alleviation emerges as a consistent and growing priority. The success of these 
efforts has given rise to a major development in the structure of political support. Cardoso was first elected on the merits of the real plan, which raised real incomes for the poor, and Lula's political success rides on the back of the government's expanding income transfer programs. Raising the standard of living is not only a moral duty, it is a political obligation. Impoverished sectors of society constitute a mass of voters that cannot be ignored. Consequently, the vision for development must benefit them. International agents now also greatly affect the course of policymaking. No were is this more evident than in the havoc created by international investors in 2002, but both the Cardoso and Lula administrations consistently worked to attract international financiers. The greater the links from the outside world, the more international agents will hold the capacity to exert influence over the political process.

The formulation of macroeconomic policy reflects the perceived need of foreign capital in Brazil, not the pursuit of a free market. The debt crisis of the 1980s created an unavoidable obstacle to government. The crisis arose from a dependency on foreign capital and the only way to ameliorate the prevailing instability was to attract more foreign capital, in order to repay debts. Starting with the real plan, monetary policy exhibited a level of government intervention and control that rivals the pinnacle of protectionist trade policies under ISI. Manipulation of the currency exchange value and interest rates was maintained to attract international capital, toward the end of creating the conditions seen as necessary for resumed development and growth. While it is true that theories compete to explain how development best occurs, government intervention remains the means to correct failures. This tendency has remained in the case of both market and government failures. In the area of macroeconomic policy, the side effects of the emphasis on short term stability soon clashed with other objectives, bring to bear the fact that macroeconomic policy is not the only variable in development. Economic stability has proven to be an important 
step, but the evolution of policy making over this period reveals that the produced by Brazil's monetary regime require effective and strategic forms of intervention in the productive and social structures.

Though the economic development strategies pursued under the FHC and Lula administrations differ in action, they share a fundamental objective: the insertion of the Brazilian economy in the global market. For better or for worse, trade with other countries has been embraced as a means to Brazil’s economic development. In practice, this has taken diverse forms, first appearing in the drastic reduction of trade barriers and the increased role of foreign ownership, and later embodied in the active promotion of export competitiveness. In all cases, the government has acted to remedy failures in productivity, through international exposure; in competitiveness, through providing financial incentives to export; and in the lack of investment, through programs designed to expand the supply of credit and increase the country's productive capacity through infrastructural projects.

State ownership in the economy has given way to public-private partnerships, with the government's role being instrumental, but not independent. This makes it difficult to ascertain whether the opening of the economy and state privatizations where the result of ideological influence, or a necessary step in reforming the mode of state intervention to one based more on cooperation than imposition. While the prevalence of neoliberal ideology should be acknowledged as a factor, one must also note that authoritarianism accompanied Brazil's expansive and monolithic development state, so the democratization of Brazilian governance puts limits on state autonomy. The introduction of civil society into the political framework necessitated a complimentary cooperative relationship in economic development. Furthermore, in the context of Brazil's longstanding poverty and inequality, political pressure, along with the 
rights enshrined in the 1988 constitution, demanded that part of the ensuing development strategy involve actions to increase the base standard of living.

Continuity also characterizes social policy objectives throughout the two administrations. Poverty alleviation and social security reform each played a major role in the agendas of both governments. While social security reform played into the austerity measures taken by both governments, it also sought to prevent abuses of the pension system, reflecting the calls by both for increased transparency and reduced corruption. Moreover, the most widely lauded aspect of the Lula government—establishing and strengthening a base level of income through government coordinated transfers and increases in the minimum wage- worked off of the many innovations made during the Cardoso administrations. In this respect, the actions of the two governments may be seen as working hand in hand. While targeting the poorest in society may be seen as a palliative for the detrimental effects of neoliberal policy-making, this assertion seems to ignore the chronic issue of poverty in Brazil, and the unequal share of wealth produced under the former development model. In this area, the policies of this period have produced unprecedented results. In contrast with the traditional role of government, social policy in the contemporary period has actively sought to include more citizens in formal society in the short term. This indicates that, rather than deserting its role in promoting societal development, the government has become more active in this respect.

Dual meaning of action and apparent contradictions appear throughout the new, emergent development model. This suggests that, rather than moving toward a single model of development, produced by a single vision, development strategies in Brazil form through a pluralistic process. The new development model is one without a singular truth; instead it makes use of a variety of theoretical paradigms to accomplish what is for now, a number of common 
objectives: (i) a globally competitive productive structure, (ii) a macroeconomic environment that attracts foreign capital, and (iii) a more equitable distribution of wealth. In identifying the character of postmodern development, we assert that analyses of government policies during the period under question should resist over asserting the influence of ideology in policy making. In Brazil's case, the effects of radical changes in the national political structure explain many of the new approaches adopted, and the new role assumed by the government in its promotion of development. 


\section{References}

Affonso, R., \& Silva, P. (Eds.). (1995). Federalismo no Brasil: desigualidades regionais e desenvolvimento. Sao Paulo: Fundacao do Desenvolvimento Administrativo do Estado de Sao Paulo/Universidade do Estado de Sao Paulo.

Affonso, R., \& Serra, J. (2007). Fiscal Federalism in Brazil: an overview. Cepal Review, 91, 2951.

ABDI, (2008). An Industrial Policy for Brazil, at www.abdi.com.br/ .

Amann, E. \& Baer, W. (2002). Neoliberalism and Its Consequences in Brazil. Journal of Latin American Studies, 34(4), 945-959.

Amann, E. and Baer, A. (2000) The illusion of stability: the Brazilian economy under Cardoso. World Development. 28(10) pp. 1805-1819.

Arestis, P., Paula, L.F., \& Ferrai-Filho, F. (2007). Assessing the Economic Policies of President Lula da Silva in Brazil: Has fear Defeated Hope?, in P. Arestis and M.C. Sawyer (eds.), Political Economy of Latin America: Recent Economic Performance, Palgrave Macmillan.

Bacha, E.L. (1994). O fisco e a inflação: uma interpreção do caso brasileiro. Revista de Economía Politica, 14(1), 5-17.

Baltar, A.P.E., Krein, J.D., Leone, E., Maia, A.G., Moretto, A., Proni, M.W., et al., (2010). Moving towards Decent Work. Labour in the Lula government: reflections on recent Brazilian experience. Global Labour University Working Papers, Paper NO. 9, May 2010.

Barbosa-Filho, N.H. (2008). An Unusual Economic Arrangement: The Brazilian Economy during the First Lula Administration, 2003-2006. International Journal of Politics, Culture, and Society, 19, 193-215.

Baumann, R. (2001). Brazil in the 1990s: an economy in transition. Cepal Review, 73, 147-169.

Beltrão, K.I., Pinheiro, S.S., Peyneau, F.P.L., \& Mendonça, J.L.O. (2005). The 1988 Constitution and Access to Social Security in Rural Brazil: Towards Universalization. In Ana A. Camarano (ed.). Sixty plus: the elderly Brazilians and their new social roles. Rio de Janeiro, IPEA: Ch. 10. 
Bonturi, M. (2002). The Brazilian Pension System: Recent Reforms and Challenges Ahead. OECD Economics Department Working Papers, No. 340, OECD Publishing. doi: $10.1787 / 251552114651$.

Brazil, (2002) Dívida Pública: Conceitos Básicos Fatores Determinantes. Brasília: Ministério da Fazenda, Secretaria do Tesouro Nacional, From: www.tesouro.fazenda.gov.br.

Brazil, (2005) Orçamento Social do Governo Federal 2001'2004. Brasília: Ministério da Fazenda, Secretaria de Política Econômica.

Câmara da Reforma do Estado. (1995). Plano Diretor da Reforma do Aparelho do Estado. Brasilia, DF.

Central Bank of Brazil (2006): Informações cadastrais e contábeis, Sistema Financeiro Nacional, Brasilia. From: http://www.bancocentral.gov.br.

Costa, N.R. (2009). Social Protection in Brazil: universalism and targeting in the FHC and Lula Administrations. Ciência \& Saúde Coletiva, 14(3), 693-706.

Doctor, M. (2007). Lula's Development Council: Neo-Corporatism and Policy Reform in Brazil. Latin American Perspectives, 34 (6), 131-148. (2009). Furthering Industrial Development in Brazil: Globalization and the National Innovation System. Paper prepared for Latin American Studies Association, Rio de Janeiro, June 2009.

Faria, V.E. (2002). Institutional Reform and Government Coordination in Brazil’s Social Protection Policy. Cepal Review, 77, 7-24.

Fenwick, T.B. (2009). Avoiding Governors The Success of Bolsa Família. Latin American Research Review, 44(1), 102-131.

Ferrari-Filho, F. \& Paula, L.F. (2003). The Legacy of the Real Plan and an Alternative Agenda for the Brazilian Economy. Investigación Económica, 244, 57-92.

Ferraz, J.C., Kufler, D., \& Iootty, M. (2004). Industrial Competitiveness in Brazil: ten years after economic liberalization. Cepal Review, 82, 91-117.

Fleisher, D. (1998). The Cardoso Government's Reform Agenda: A View from the National Congress, 1995-1998. Journal of Interamerican Studies and World Affairs, 40(4), 119136.

Furtado, J. \& Suzigan, W. (2006). Industrial Policy and Development. Cepal Review, 89, 69-84. 
Giambiagi, F. \& Ronci, M. (2005) Brazilian Fiscal Institutions: the Cardoso Reforms, 19952002. Cepal Review, 85, 59-77.

Gomide, A.A., Loureiro, M.R., \& Santos, F.P. (2009). Democracy and Macroeconomic Policymaking in Brazil: the fiscal agenda of the Lula administration. From the XIV Encontro Nacional de Economia Política. Retrieved from: http://www.sep.org.br/

Hall, A. (2008). Brazil's Bolsa Familia: A Double-Edged Sword?” Development and Change, 39 (5), 799-822.

Instituto Brasileiro de Geografia e Estatística. www.ibge.gov.br. Accessed July, 2010. Instituto de Pesquisa Econômica Aplicada - IPEADATA. www.ipeadata.gov.br. Accessed July, 2010.

Krueger, A. (1990). Government Failures in Development. The Journal of Economic Perspectives, 4(3), 9-23.

Lal, D. (1983). The Poverty of Development Economics. Cambridge: Harvard University Press. Leiva, F.I. (2008). Latin American Neostructuralism: The Contradictions of Post-Neoliberal Development. Minneapolis: University of Minnesota Press.

Lustig, N. (1991). From Structuralism to Neostructuralism: The Search for a Heterodox Paradigm. In P. Meller (Ed.), The Latin American Development Debate (27-42). Boulder: Westview Press.

Macedo, R. (2003). Macroeconomic Volatility and Social Vulnerability in Brazil: The Cardoso Government (1995-2002) and perspectives. CEPAL-SERIE financiamento del desarollo, 132, Santiago: United Nations.

Molyneaux, M. (2008). The 'Neoliberal Turn' and the New Social Policy in Latin America: How Neoliberal, How New? Development and Change, 39 (5), 775-797.

Nakahodo, S.N., \& Savoia, J.R. (2008). A Reforma da Previdência no Brasil: Estudo comparativo dos governos Fernando Henrique Cardoso e Lula. Revista Brasileira de Ciências Sociais, 23(66), 45-58.

Pereira, L. C. B. (2009). Developing Brazil: Overcoming the failure of the Washington consensus. Boulder, Colo: Lynne Rienner.

Pinheiro, M.C. (2009). Bolsa Família ou Desempenho da Economia? Determinantes da Reeleição de Lula em 2006. Texto para Discussão 2, IBRE, Fundução Getulio Vargas. 
Power, T. (2001-2002). Blarisim Brazilian Style? Cardoso and the "Third Way” in Brazil. Political Science Quarterly, 116(4), 611-636.

Prebisch, R. (1950). The Economic Development of Latin American and its Principal Problems. New York: United Nations.

Rabelo, F. \& Vasconcelos, F. (2002). Corporate Governance in Brazil. Journal of Business Ethics, 37, 321-335.

Rocha, R. \& Soares, R.R. (2009). Evaluating the Impact of Community-Based Health Interventions: Evidence from Brazil's Family Health Program. IZA Discussion Paper, No. 4199, April 2009.

Samuels, D. (2003). Fiscal Straitjacket: The Politics of Macroeconomic Reform in Brazil, 19952002. Journal of Latin American Studies, 35(3), 545-569.

Singer, H. (1949) Post-War Relations between Under-developed and Industrialized Countries. New York: United Nations.

Skidmore, T.E. (1973). Politics and Economic Policy Making in Authoritarian Brazil, 1937-71. In A. Stepan (Ed.), Authoritarian Brazil (pp. 3-46). New Haven: Yale University Press.

Sunkel, O. \& Zuleta, A. (1990). Neo-structuralism vs. Neo-liberalism in the 1990s. Cepal Review, 42, 35-51.

Vidal Luna, F. \& Klein, H. S. (2006) Brazil Since 1980. New York: Cambridge University.

Werneck, R.L.F. (2006). An Evaluation of the 2003 Tax Reform Effort in Brazil. Brazilian Journal of Political Economy, 26(1), 75-94.

Weyland, K. (2004). Threats to Latin America’s Market Model? Political Science Quarterly. 119(2), 291-313. (1997-1998). The Brazilian State in the New Democracy. Journal of Interamerican Studies and World Affairs, 39(4), 63-94.

Williamson, J. (1990). What Washington Means by Policy Reform, in Latin American adjustment: How much has happened? Washington, D.C: Institute for International Economics. 